\title{
ASSESSMENT OF THE RISKS OF LEVEL CROSSINGS IN THE MORAVIAN-SILESIAN REGION AND PROPOSED SAFETY MEASURES
}

Iva ŽITNÍKOVÁ ${ }^{1}$, Michal SCHWARZ², Aleš BERNATÍK ${ }^{3}$

Research article

Abstract: $\quad$ Many casualties and injuries are still connected with level crossings in the Czech Republic.
For this reason, a theme for the project “Assessment and Management of Level Crossing
Risks” with the goal to make a comprehensive analysis of the safety of level crossings
in the Moravian-Silesian Region, arose. The following text gives a summary of dealing
with this project, which included both the considerations about the problem from the
legislative and the technical point of view, and the problem of human errors affecting
crucially the occurrence of level crossing incidents. Based on the carried out analyses,
technical, organisational and educational measures to reduce risks related to the operation
of level crossings were proposed.
Level crossing, risk analysis and assessment, measures to reduce risks, safety.

\section{Introduction}

Owing to a still high number of level crossing incidents, the Union for the Development of the Moravian-Silesian Region and the Czech Technology Platform on Industrial Safety submitted a topic for the project "Assessment and Management of Level Crossing Risks", in which the Railway Infrastructure Administration (henceforth referred to as SŽDC) also participated. In the introductory part of the project, an overview of legislation concerning level crossings and a general theory of types of level crossings in the Czech Republic and abroad are presented. In the second part of the project, statistics for level crossing accident rates in the world, in the Czech Republic, and in the Moravian-Silesian Region are provided. Particular factors affecting the occurrence of level crossing incidents are plotted and evaluated graphically. The project included a questionnaire survey on the topic "Perception of Level Crossing Risks". The fourth part of the project is devoted to the analysis of level crossing risks. Selected scenarios of incidents that may occur on specific level crossings are evaluated using different methods. In the next part, the selected scenarios are dealt with and modelled on the specific level crossings. At the end, all parts of the project are evaluated and measures are proposed to reduce level crossing risks and to decrease the number of incidents and thus the number of injured persons.

\section{Materials and Methods}

\section{Level Crossings}

A level crossing according to Act No. 266/1994 Coll., on rail systems as subsequently amended (Zákon, 1994) is defined as a point of a railway crossing with a surface road at the level of rails. In the mentioned Act, Section 6, it is stated that if the railway is crossing a road at the level of rails, the rail transport operation shall have the right of way over the transport on road communications. Each level crossing, regardless the type of level crossing, must be equipped with a crossbuck or another type of crossing safety device. If all the standards, decrees and regulations on the design, construction and maintenance of level crossings are fulfilled, level crossings can be regarded as safe. In spite of the fact that the above-mentioned legal aspects are satisfied, many people die annually of just level crossing accidents.

\section{Rate of Level Crossing Accidents in the Moravian-Silesian Region}

The level crossing accidents do not avoid the Moravian-Silesian Region (henceforth referred to as MSR), to which the project was orientated, either. In the territory of MSR, there are 647 level crossings falling within the scope of SŽDC Ostrava (see Tab. 1).

\footnotetext{
VŠB - Technical University of Ostrava, Faculty of Safety Engineering, Ostrava, Czech Republic, iva.zitnikova@centrum.cz VŠB - Technical University of Ostrava, Faculty of Safety Engineering, Ostrava, Czech Republic

VŠB - Technical University of Ostrava, Faculty of Safety Engineering, Ostrava, Czech Republic, ales.bernatik@vsb.cz
} 
Tab. 1 Overview of level crossings in MSR

\begin{tabular}{|c|c|c|}
\hline \multicolumn{3}{|c|}{$\begin{array}{c}\text { Overview of level crossings on lines in MSR - by } \\
\text { type of safety device }\end{array}$} \\
\hline \multicolumn{2}{|l|}{ Crossings equipped merely with a crossbuck } & 398 \\
\hline \multicolumn{2}{|c|}{$\begin{array}{l}\text { Crossings equipped with a crossing safety device } \\
\text { (CSD) }\end{array}$} & \multirow{3}{*}{249} \\
\hline $\begin{array}{l}\text { Crossings equipped with warning lights } \\
\text { - total }\end{array}$ & 235 & \\
\hline $\begin{array}{l}\text { Crossings equipped with a mechanical } \\
\text { CSD }\end{array}$ & 14 & \\
\hline Total number of crossings & \multicolumn{2}{|c|}{647} \\
\hline
\end{tabular}

In the years 2005 - 2009, 101 accidents occurred at these crossings; 56 persons were injured, 19 persons died and altogether the value of damage to property exceeded CZK 16.5 . 106 (SDC Ostrava, 2005 - 2009). The numbers of accidents in individual years in the given area are presented in Graph 1.

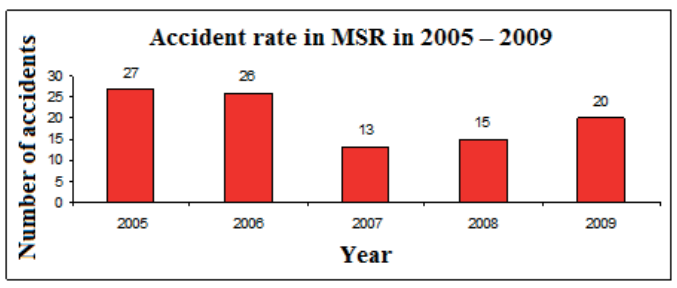

Graph 1 Accident rate in MSR in 2005 - 2009

To assess the accident rate in this region, rather detailed analyses for the period of last five years, i.e. the years 2005 - 2009, were carried out. As an example, Graph 2 is given below.

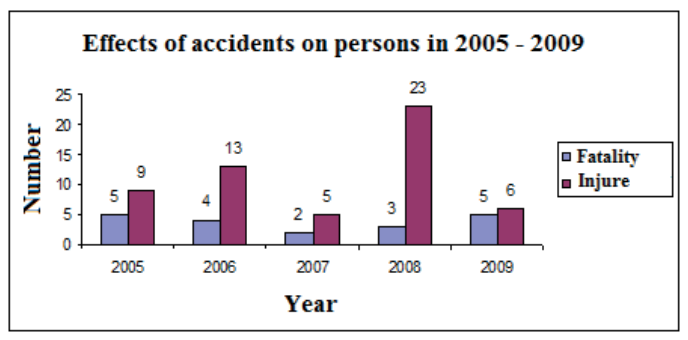

Graph 2 Effects of accidents on persons in 2005 - 2009

\section{Perception of Level Crossing Risks}

Too often, tragic level crossing accidents are reported in the news; the main reason of them being a driver's error. The knowledge of human failure causes can help finding effective pathways to prevent the failure. All road traffic participants know what traffic lights look like, what is the meaning of the lights signalling, and know what to do when the red, yellow, and green lights are on. However, what is the cause of the fact that red lights at level crossings are not perceived and respected to the same degree as red lights at crossroads? If we think about this, consequences of showing little respect for them at level crossings are usually more serious than at crossroads.

An incentive for the creation of the questionnaire was just this different behaviour of and perception of possible risks by drivers and also other road traffic participants on level crossings and at the junction.

\section{Questionnaire Survey}

The aims of the questionnaire survey were:

- To define and specify the road traffic participants at level crossings who took part in the questionnaire survey.

- To evaluate the knowledge of road traffic participants in the area of level crossings.

- To evaluate the influence of external conditions and stereotype on the satisfaction of level crossing regulations.

- The view of road traffic participants of the perception of level crossing risks.

To accomplish the set objectives, the method of sociological survey, namely written questioning, was used. The questionnaire was anonymous and comprised 13 closed questions.

\section{Outputs of Questionnaire Survey}

Altogether, 340 questionnaires were sent to respondents in the period from the beginning of July to the end of September 2010; 175 questionnaires were returned completed.

Participants in the survey were men and also women of various age groups, with different lengths of driving experience. From the evaluation of the questionnaires it followed that two thirds of respondents were men; the 25 - 34 year age group was the largest. From the questionnaire it has been found that respondents e.g.:

- consider a level crossing a crossroads,

- have most frequently failed to notice and crossed a level crossing equipped with a crossbuck,

- know the speed with which they are permitted to enter a level crossing,

- state that the most frequent cause of failing to notice signs and markings and of passing through a level crossing is the fact that the driver is in a hurry and ignores traffic signs and markings,

- do not know any campaign focused on level crossing safety. (Žitníková et al., 2010). 


\section{Results}

\section{Analysis of Level Crossing Risks}

The basic step in the process of reducing risks is naturally the analysis of the risks. The risk analysis is usually understood as a process of the determination of threats, the probability of the implementation of these threats and their consequences, i.e. the determination of risks and the severity of risks. The risk analysis becomes the decisive basis for the process of the elimination of level crossing risks.

The aim of the analysis is to assess level crossing risks using selected methods. We assessed the risks as a whole set; however, for obtaining more accurate results of specific level crossings, it is more suitable to approach every level crossing individually and thus take into account given properties of the level crossing, the amount of traffic on it, local conditions, and others.

\section{Description of System Evaluated}

In the first stage, it was necessary to define the boundaries that would be used for the risk analysis. For the needs of the risk analysis, these boundaries were divided into two areas: legislative framework and level crossing itself.

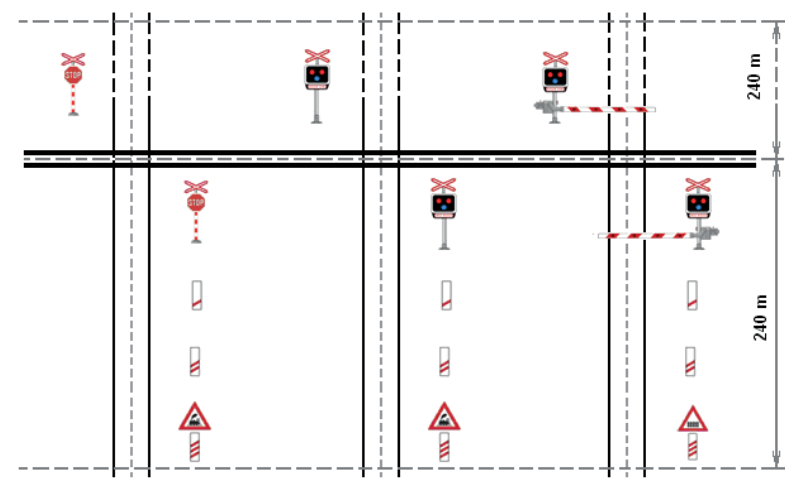

Fig. 1 Railway crossing boundaries for carrying out the risk analysis

For carrying out the risk analysis, level crossing boundaries running from a traffic sign showing a $240 \mathrm{~m}$ distance from the level crossing as illustrated in Fig. 1 were determined. From this point, selected methods of risk analysis will be applied.

Furthermore, level crossing traffic participants had to be defined generally, i.e. road traffic participants as well as railway traffic participants. The following step was the specification of dangerous substances (toxic, combustible, explosive, and others). For the needs of the risk analysis, substances were divided into liquid and gaseous substances as shown in Fig. 2. The kind and the type of chosen substances correspond best to materials transported by road as well as by rail.

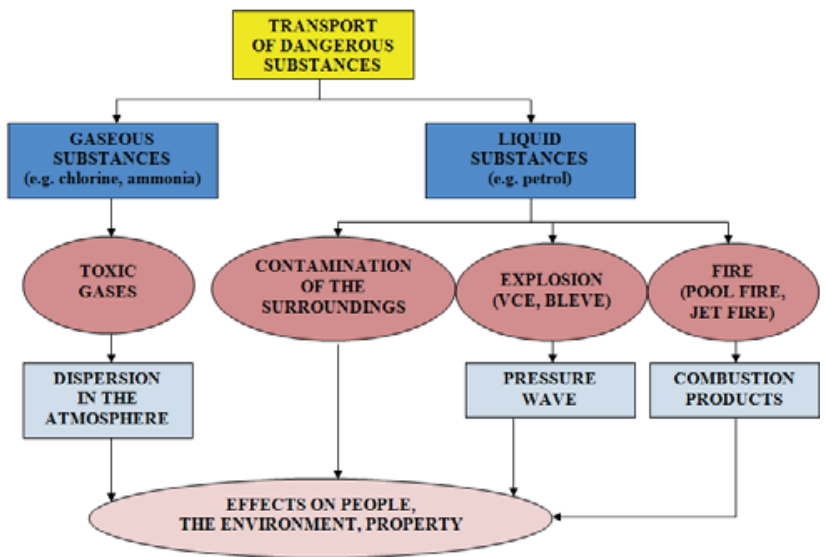

Fig. 2 Overview of possible scenarios of incidents during the transport of dangerous substances, modified according to (Přibyl et al., 2010)

\section{Carrying out the Risk Analysis}

For carrying out the risk analysis, the following procedure was proposed:

1)application of "What - If" method,

The method "What - If" processes in a form of scenarios the incidents that may occur on a level crossing. Not all the combinations of crushes between cars and rail means of transport are included here. The considered scenarios can affect both traffic participants (injuries, casualties, financial losses) and the proper surroundings of the level crossing (endangering persons in the vicinity of the level crossing, potential affection of individual components of the environment by a dangerous substance). The following representative scenarios were selected:

a)an accident between a tank lorry transporting a dangerous substance and a passenger train (in combination with the injury of participants and release of dangerous substance - 1A - 1D),

b)an accident between a tank lorry and a goods train - both transporting dangerous substances (in combination with the injury of participants and release of dangerous substance - 2A - 2D),

c) an accident between a car and a passenger train (with/without the injury of participants - 3A - 3B)

d)an accident between a bus and a passenger train (with/without the injury of participants - 4A - 4B).

These selected representative scenarios serve as input data for the FMEA method. 


\section{2)application of FMEA method.}

The analysis of risks was made using the method FMEA in a form of tables. For the analysis, the below mentioned formula and indices are used as a basis:

$$
R P N=S \cdot O \cdot D
$$

\section{$R P N$ Risk Priority Number,}

$S \quad$ dimensionless number that classifies severity,

$O \quad$ classifies occurrence probability,

$D \quad$ classifies detection, i.e. how likely it is for a failure to be identified or detected (ČSN, 2007).

Values calculated from the above-mentioned formula (1) for the level of risk are included in Graph 3. The risk level moves in the interval $(0,1000>$. Real up to slightly overestimated values of particular indices are selected to increase safety.

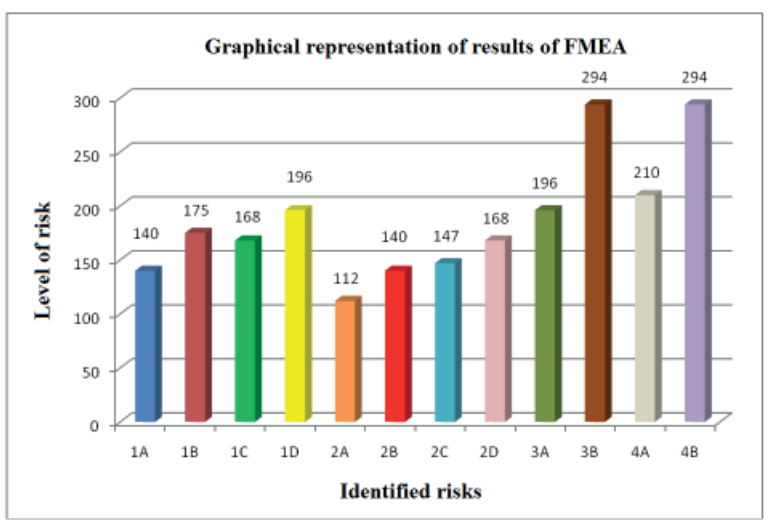

Graph 3 Graphical representation of results of FMEA

\section{Results of Risk Analysis}

From the above-mentioned and performed analyses it has followed that the most severe risks are:

1-2) 294 points

3) 210 points

4-5) 196 points
4B A crash between a bus and a passenger train involving the injury of accident participants.

3B A crash between a car and a passenger train involving the injury of accident participants.

4A A crash between a bus and a passenger train involving no injury of accident participants.

1D A crash between a tank lorry transporting dangerous substances and a passenger train involving the injury of participants and the release of dangerous substance.

3A A crash between a car and a passenger train involving no injury of accident participants.

\section{Discussion of Results}

As a consequence of crash between a bus and a passenger train, a high number of people are potentially endangered. Many passengers may be injured and killed. With such incident, a difficult intervention of fire brigades and the emergency treatment of injured persons by emergency medical service are connected. People who are participants in such an accident may suffer psychical injury/ trauma that will accompany them for the rest of their lives. As a consequence, they will not be able to travel by such means (bus, train) any more in order to avoid the same situation. In a crash between a car and a passenger train, an important factor is the high probability of accident occurrence, because the frequency of cars is the highest of the frequencies of all above-mentioned means of transport. Moreover, in the course of evaluation of basic data on level crossing accidents, the majority of accidents were caused by drivers of cars. As for a crash between a tank lorry transporting dangerous substances and a passenger train, it is obvious that the most important factor is the number of directly affected people as a consequence of potential accident/traffic accident at the level crossing (either direct endangering passengers' health, or endangering the health of the driver of the tank lorry due to the accident or the release of dangerous substance).

\section{Proposed Measures}

The proposed measures following from the comprehensive solving of the problems of level crossings could be divided, according to their character, into the following three groups: technical measures, organisational measures and educational measures. The specific groups are characterised and analysed below.

\section{1) Technical Measures}

Technical measures are such measures that eliminate the occurrence of a fault. They should be as cheap as possible yet effective.

\section{a) Replacement of Gate}

An effective way to prevent the entry to the crossing is to replace the existing protection gate by another type of barrier that should completely prevent the entry. This is of course very expensive but well-tried, e.g. in Spain. Crossings are protected here by means of rising posts. The level crossing is equipped with an optical and an acoustic signalling device; after their activation, the posts start to rise from the ground. This type of protection has replaced the existing gate (barrier). This type of protection is not entirely unknown in the Czech Republic. It 
can be met on roads, but not at level crossings. The advantages of the application of such protection equipment to level crossings are an increase in safety and the prevention of vehicles entry to level crossings. The disadvantages of this piece of equipment are the costs of purchase and assembly.

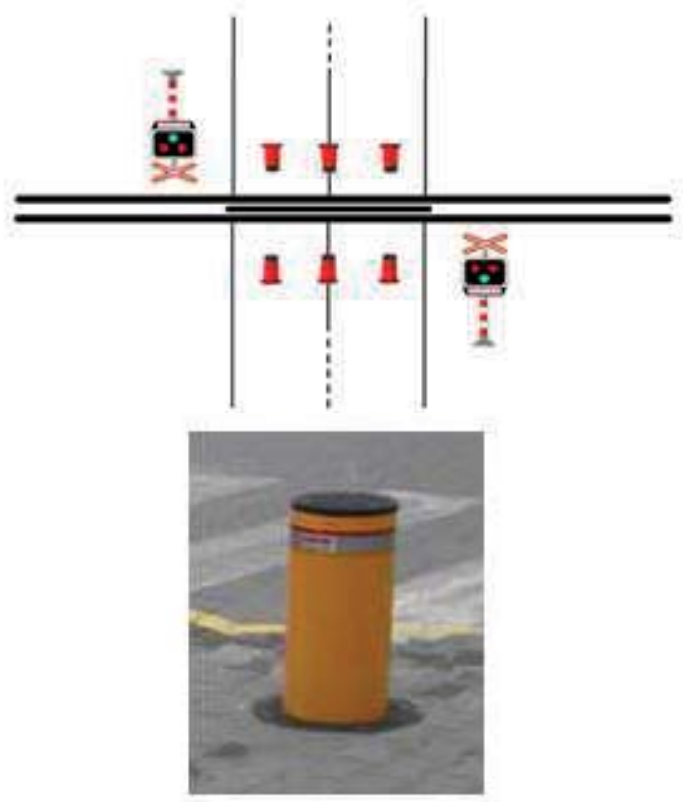

Fig. 3 Rising posts

\section{b) Change in Type of Optical Signalling Device}

As for light signalling devices, it would be suitable to use diodes instead of present-day lights. Diodes can be seen better even when blinded by sun glare, in fog, under the conditions of poor visibility, and others. New indicators using LED technology have already been tested in the Czech Republic. By testing it has been found that the lights can be seen much better in sharp sunshine; even from the extreme angles of view, when the light of lamps is less visible. The advantages are the longer life of LEDs and the fact that each of three lights of the indicator is fitted with 137 LEDs that are electronically divided into three independent circuits - segments. In case of fault in one circuit, the remaining LEDs (about $90 \mathrm{pcs}$ ) emit light sufficient for fulfilling standards and regulations on the luminous intensity of indicators. (Silnice a železnice, 2010).

\section{c) Change in Traffic Signs}

For the selected level crossings with an increased number of traffic accidents, we recommend to use a warning traffic board "Caution, frequent accident level crossing" (see Figure 4) similarly to road traffic, where in the selected parts there are traffic signs warning of frequent accident points. The designed traffic sign could be classed to the group of warning traffic signs and designated as sign No. A 34; in combination with the traffic sign No. A 31c it could ( $80 \mathrm{~m}$ ahead of crossing) warn of a level crossing at which traffic accidents occur frequently. (Žitníková et al., 2011)
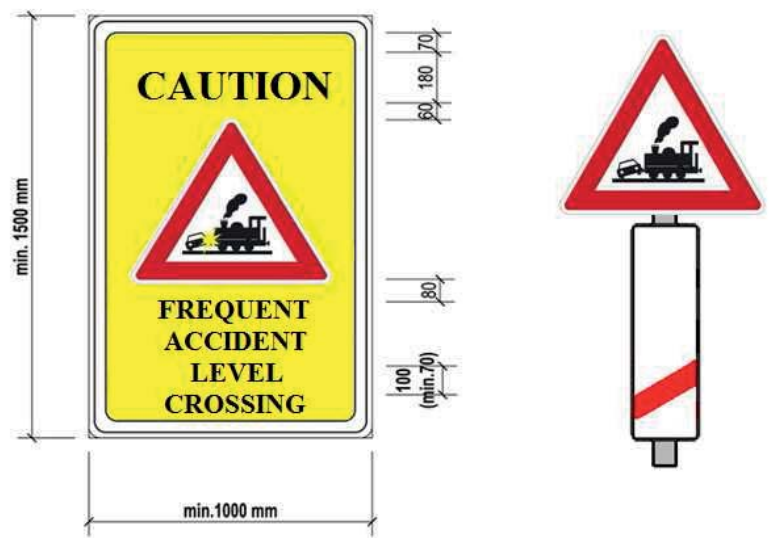

Fig. 4 Design of traffic sign "Caution, frequent accident level crossing"

\section{d) Making Traffic Signs More Conspicuous}

An important point is also making level crossing signs more conspicuous. It would be suitable to use red reflex reflectors, which can be seen better by drivers under the conditions of poor visibility, instead of red stripes.

\section{e) Additional Markings}

To additional markings, light guide strips (cat's eyes) belong. A light strip would either draw the attention of drivers to the level crossing permanently, or the lights would be switched on after the activation of the crossing safety device by a coming rail vehicle. Before the level crossing, drivers would be warned by means of a row of highintensity LED warning lights placed across the road. Another possible way of road marking would be the use of so-called "optical-psychological brake" with acoustic effect, such as several stripes running across the road before a level crossing. These manners have already been dealt with in a project of Ministry of Transport (Ministry of Transport, 2010).

\section{f) Camera System and Dummy Cameras}

An effective way to prevent passing through level crossings after activation of signalling devices is the installation of cameras that begin recording simultaneously with the activation of signalling devices or shortly before the activation. If the driver is aware that his/her behaviour is being observed, his/ her behaviour is more responsible and in accordance with regulations. This manner of prevention is already utilised in some places; however, this method is very difficult from the organisational point 
of view (records must be checked, drivers breaking regulations must be identified and fined), from the financial point of view and also from the safety point of view. The proper purchase and operation of a camera system is expensive, not mentioning the fact that cameras may be stolen or destroyed. For this reason, cameras could be replaced by dummy cameras, and from time to time, moved from the level crossings where they are used to other selected level crossings.

\section{g) To Execute Changes}

The purpose of this measure is to execute such changes in a signalling device and in its immediate surroundings that will be able to disturb the driver's stereotyped acting, such as change in the sound of the signalling device, etc., but will be in accordance with relevant standards and regulations.

\section{2) Organisational Measures}

Organisational measures should be divided according to their scope of competence and powers.

\section{a) Police of the Czech Republic, Municipal Police}

- more frequent inspection of traffic at level crossings, fining of drivers breaking the road traffic regulations,

- interpretation of camera records,

- organisation of educational actions for children in schools.

\section{b) Employee of SŽDC - Rail Transport Engineer}

- to keep regular checks of signs and markings,

- to keep regular checks of sight conditions,

- to keep regular checks of functionality of signalling devices,

- all checks should be conducted by a person unfamiliar with the given level crossing and its surroundings to avoid ignoring possible worsened conditions owing to the good knowledge of local conditions and stereotype.

\section{c) In General}

- formation of a database on hazardous crossings in the region,

- clarification of competence, authorities and responsibilities of organisations as for individual safety devices, signs and markings, and others,

- making legislation and recourse stricter in the case of not obeying the regulations of road traffic at level crossings,

- preparation of publications, leaflets on "How to behave at level crossings?" and "How to behave at a level crossing in case of accident?",

- media pressure, better awareness, e.g. of accident rate statistics,
- not to carry out nationwide media campaigns, but to focus on specific areas, regions, because people are more sensitive to and interested in things that happen in their surroundings than at the other end of the country.

\section{3)Educational Measures}

Educational measures are to increase the public awareness of hazards associated with level crossings, of the prevention of these hazards and of how to behave in the case of accident at a level crossing.

The proposals are divided into groups according to the target groups for which they are intended:

\section{- basic schools}

- inclusion of educational actions and traffic education in the teaching-learning process at basic schools,

- distribution of instructional films on behaviour at level crossings to schools,

\section{- driving schools}

- to increase attention paid to level crossing problems in teaching at driving schools,

- by driving simulators, instructional films drawing attention to hazards by means of information on road traffic regulations when passing through level crossings and information on how drivers and other persons are to behave if being a participant in an level crossing accident (where to call, what to report, etc.),

\section{- the public}

- information on behaviour at level crossings intended for drivers and also for pedestrians,

- fining pedestrians, cyclists for going around the closed gate at level crossings.

In the course of implementation of these measures, attention should be paid especially to feedback. This means that after a given time period, tests and surveys will be carried out that will verify the efficiency of measures implemented. (Žitníková et al., 2011).

\section{Conclusion}

The goal of the project on the topic "Assessment and Management of Level Crossing Risks" dealt with for several months was to make a comprehensive analysis of the safety of level crossings in the Moravian-Silesian Region, covering technical as well as legislative aspects and also human factor issues. 
Of the above-mentioned proposed measures to reduce risks, the following measures are recommended preferentially:

\section{- Increase in the level of level crossings protection} (installation of gates).

- Making level crossing additional signs and markings more conspicuous (optically and acoustically).

\section{- Improvement of awareness and education of} road traffic participants (campaigns, driving schools, pupils of basic schools and students of secondary schools).

\section{Acknowledgements}

This contribution was prepared in the framework of the project of Student Grant Competition of VŠB - Technical University of Ostrava "Hodnocení a řízení rizik železničních přejezdů” (Žitníková a spol. 2010) (Assessment and Management of Level Crossing Risks), No. SP/2010126.

The contribution was prepared thanks to the support to science and research provided from the budget of Moravian-Silesian Region, agreement No. 01737/2010/RRC.

\section{References}

PŘIBYL, P., JANOTA, A., SPALEK, J. (2008). Analýza a ř́zení rizik v dopravě. 1. vyd. Praha: Nakladatelství BEN - technická literatura, 2008. 528 s. ISBN 978-80-7300-214-5.

ŽITNÍKOVÁ, Iva et al. (2010). Hodnocení a řizení rizik železničních přejezdů. [Studentská grantová soutěž VŠB - Technická univerzita Ostrava]. Ostrava: VŠB - TUO, 2010, č. SP/2010126.

ŽITNÍKOVA, Iva, MALEROVA, Lenka, PRIBYL, Rene, SCHWARZ, Michal, BERNATIK, Ales, KOPECKA, Lenka (2011). Assessment and Management of Level Crossing Risks. In Communications - Scientific Letters of the University of Zilina, 2011, Vol. 13, No. 2, pp. 78-82. ISSN 1335-4205.

Silnice a železnice (2010). Poprvé v ČR: Vlakové přejezdy s LED výstražníky [online]. Doprava [cit. 2010-10-01]. Dostupný z: http://www.silnice-zeleznice.cz/clanek/poprve-v-cr-vlakove-prejezdy-s-led-vystrazniky/.

Ministerstvo dopravy (2010). Typizace zvýšení bezpečnosti železničních přejezdư, návrh organizačních a technicko - stavebních opatření [online]. Ministerstvo dopravy [cit. 2010-09-20]. Dostupný z: http://www.mdcr.cz/cs/ Drazni_doprava/Bezpecnost_prejezdy/prejezdy_bezpecnost.htm.

Zákon č. 266/1994 Sb., o dráhách, ve znění pozdějších změn a úprav.

ČSN EN 60812:2007. Techniky analýzy bezporuchovosti systémů - Postup analýzy způsobů a důsledků poruch (FMEA).

SDC Ostrava (2005-2009). Zprávy o šetřeni mimořádných událostí, Interní materiály poskytnuty Správou Železniční dopravní cesty, s.o. 